\title{
PENERAPAN PROGRAM IPTEKS BAGI WILAYAH (IbW) \\ DI KECAMATAN NUSA PENIDA \\ KABUPATEN KLUNGKUNG \\ TAHUN 2012
}

\author{
I Nyoman P Suwindra \\ Jurusan Pendidikan Fisika \\ Fakultas Matematika dan Ilmu Pengetahuan Alam \\ Universitas Pendidikan Ganesha
}

\begin{abstract}
ABSTRAK
Program Ipteks bagi Wilayah (IbW) di Kecamatan Nusa Penida, Kabupaten Klungkung tahun 2012 ditujukan untuk memberdayakan potensi yang ada di masyarakat. Sebagai upaya untuk meningkatkan kesejahteraan masyarakat, pemberian bantuan Iptek dari Perguruan Tinggi, dukungan Pemda, serta peran partisipasi masyarakat menjadi hal yang sangat penting. Bidang-bidang yang menjadi fokus perhatian dalam program ini adalah bidang pendidikan, pertanian-peternakan, industri rumahan, infrastruktur, dan lingkungan hidup. Desa lokasi program IbW Nusa Penida adalah Desa Suana, Desa Batukandik, dan Desa Sakti. Program ini dilaksanakan melalui metode/model: Partisipatory Rural Apprasial (PRA), Enthrepreneurship Capasity Building (ECB), Technology Transfer (TT), dan Information Technology (IT), dalam berbagai bentuk kegiatan seperti pendidikan dan pelatihan (diklat), pembinaan dan pendampingan, penyuluhan, percontohan (demplot), dan penghijauan. Adapun hasil dari kegiatan ini adalah; (1) meningkatnya pengetahuan dan keterampilan dalam bidang komputer bagi staf desa, kecamatan, dan guru-guru SD; (2) meningkatnya pengetahuan dan keterampilan bagi anggota kelompok Sari Gading bidang pembuatan VCO; (3) membuat demplot biogas bagi petani; (4) meningkatkan keterampiran proses pembelajaran bagi bagi guru-guru PAUD; (5) meningkatnya keterampilan masyarakat sesuai minatnya sambil mereka belajar membaca dan berhitung; (6) meningkatkan keterampilan membuat media pembelajaran IPA berbasis lokal; (7) meningkatkan kualitas batako dan dampak lingkungan; (8) meningkatnya pengetahuan masyarakat tentang cara pembibitan dan menanam pohon penghijauan sekitar 2.000 pohon jati dan karet setiap desa; (9) pengembangan budidaya jarak kepyar bekerjasama dengan Kimia Farma yang melibatkan sekitar 400 petani.
\end{abstract}

Kata-kata Kunci: pemberdayaan, masyarakat, partisipatif, biogas, VCO.

\section{Pendahuluan}

Nusa Penida adalah salah satu kecamatan di Kabupaten Klungkung yang wilayahnya terpisah dari wilayah Klungkung daratan. Nusa Penida adalah gugusan 
kepulauan yang terdiri dari 3 pulau, yaitu: Pulau Nusa Penida, Pulau Lembongan dan Pulau Ceningan. Wilayah Nusa Penida tergolong wilayah tandus, hampir 95\% daerah perbukitan, dengan puncak tertinggi adalah Puncak Mundi. Oleh karena Nusa Penida adalah wilayah kepulauan, maka wilayahnya dikelilingi lautan dengan panjang pantai sekitar $70 \mathrm{~km}$. Batas-batas wilayah Nusa Pendia adalah sebagai berikut: di sebelah Utara dan Barat adalah Selat Badung, sebelah Timur adalah Selat Lombok, dan sebelah Selatan adalah Samudra Indonesia. Kecamatan Nusa Penida terdiri dari 16 Desa Dinas, dengan jumlah penduduk 47,709 jiwa atau 8.543 KK yang terdiri dari laki-laki 23.239 jiwa dan perempuan 24.470 jiwa, antara lain: Desa Ped, Desa Tanglad, Desa Kutampi, Desa Kutampi Kaler, Desa Batununggul, Desa Suana, Desa Pejukutan, Desa Bunga Mekar, Desa Sekartaji, Desa Batumadeg, Desa Batukandik, Desa Klumpu, Desa Sakti, Desa Toya Pakeh, Desa Lembongan dan Desa Jungutbatu. Pulau Nusa Penida bisa ditempuh dari empat tempat yaitu lewat Benoa dengan menumpang Quiksilver/Balihai ditempuh dalam waktu \pm 1 jam perjalanan, lewat Sanur dengan menumpang Jukung waktu tempuh $\pm 2,5$ Jam perjalanan. Lewat Kusamba dengan menumpang Jukung butuh waktu $\pm 1,5$ jam perjalanan. sedangkan kalau lewat Padangbai dengan menumpang Boat atau Kapal RORO waktu tempuh \pm 1 jam perjalanan.

Mata pencaharian utama penduduk adalah pertanian. Di sektor perikanan termasuk rumput laut hanya sekitar 6,68\% dari jumlah penduduk yang tersebar di desa-desa pesisir yaitu Desa Suana, Desa Batununggul, Desa Kutampi Kaler, Desa Ped dan Desa Toyapakeh. Sedangkan di Pulau Lembongan sekitar 16,80\% penduduk bergerak di bidang perikanan dan rumput laut, dan di Ceningan sekitar 12,88\%. Taman laut yang ada di Nusa Penida tergolong indah dan sudah dikenal oleh turis asing dari manca Negara. Melihat kondisi dan topografi daerah maka yang cocok dikembangkan adalah sektor pertanian, perikanan dan pariwisata. Di samping sektor-sektor tersebut, sektor peternakan juga menjadi komuditas andalan penduduk di Nusa Penida. Hampir setiap keluarga memiliki ternak antara 3 sampai 5 ekor sapi, minimal 1 ekor induk babi, dan beberapa ekor ayam. Ternak sapi merupakan kebutuhan mutlak bagi petani, karena dimanfaatkan untuk membajak tanah di musim tanam. Sedangkan ternak babi hanya sekedar untuk penampung limbah dapur, dan hingga saat ini belum ada yang menjalakan usaha ternak secara khusus. 
Di antara desa-desa yang ada di kecamatan ini, maka dua desa yang menjadi lokasi program Ipteks bagi Wilayah (IbW) yaitu Desa Suanai, dan Desa Batukandik yang merupakan desa-desa yang memiliki potensi-potensi yang belum dikelola secara optimal, dan sebagian besar penduduknya masih tergolong miskin. Potensi-potensi yang paling menonjol dikedua desa tersebut, antara lain: Potensi pertanian dan perkebunan lahan kering terutama palawija, pisang, singkong, kelapa, dan pisang. Potensi peternakan yang cukup menonjol di desa-desa ini adalah peternakan sapi, babi dan ayam. Potensi perikanan, hanya Desa Suana bagian pantai penduduknya sebagian besar sebagai nelayan dan petani rumput laut dengan hasil produksi yang cukup besar. Potensi kerajinan dan industri di dua desa memiliki potensi mengolah hasil-hasil pertanian, perkebunan dan perikanan terutama pengolahan hasil pasca panen, seperti produk olahan krupuk, kripik, brownies, nugget, opak, bolu, bakso, dll, Potensi lahan tandus, masih tergolong cukup luas di kedua desa. Sementara itu, potensi pariwisata yang ada adalah wisata religi Goa Giri Putri di Desa Suana, dan mata air Guyangan, Tarian Sakral Gandrung Bangun Urip di Desa Batukandik, cukup potensial untuk dikembangkan.

Kendatipun kedua desa memiliki potensi pertanian, peternakan, perikanan, kerajinan dan pariwisata yang cukup besar, namun karena kurangnya kemampuan masyarakat di dalam mengelolanya, maka sektor pertanian, peternakan, perikanan, kerajinan dan pariwisata itu belum mampu meningkatkan kesejahteraan masyarakat secara signifikan. Di samping kurangnya kemampuan masyarakat dalam mengelola sumberdaya alam, maka masih rendahnya tingkat kesejahteraan masyarakat juga disebabkan karena belum semua potensi tenaga kerja yang ada bergerak melakukan proses produksi. Rendahnya tingkat kesejahteraan masyarakat dapat dilihat dari masih tingginya tingkat kemiskinan, rendahnya tingkat kesehatan, rendahnya tingkat pendidikan, masih tingginya angka pengangguran di masyarakat, dan masih banyak angkatan kerja menjadi buruh di kota. Terkait dengan tingginya tingkat kemiskinan dan rendahnya tingkat pendidikan masyarakat, terungkap bahwa di Desa Suana, dari jumlah penduduk 3.745 jiwa $(1.110 \mathrm{KK} / \mathrm{RT})$, yang terdiri dari laki-laki 1.410 jiwa dan perempuan 1.835 jiwa, terdapat 266 RTM (Rumah Tangga Miskin) dengan 1.101 jiwa. Sedangkan di Desa Batukadik, dari jumlah penduduknya 4.783 jiwa, yang terdiri dari 
laki-laki 2.145 jiwa dan perempuan 2.628 jiwa, 1019 orang tidak pernah mengenyam pendidikan.

Terkait dengan kekurang mampuan masyarakat dalam mengelola sumberdaya alam yang ada, maka hal ini disebabkan oleh kurangnya pengetahuan dan keterampilan pada masyarakat dalam hal meningkatkan produksi dan memasarkan hasil produksi dari usaha pertanian, peternakan, kerajinan dan industri yang ditekuni oleh masyarakat. Disamping itu, usaha-usaha yang ditekuni masih terkesan tradisional, konvensional dan tidak berorientasi bisnis, serta belum maksimalnya jumlah tenaga kerja yang mengelola sumberdaya alam yang disebabkan oleh belum dimilikinya pengetahuan dan keterampilan oleh sebagian masyarakat yang sudah memasuki usia kerja.

Dengan masih rendahnya tingkat kesejahteraan masyarakat di kedua desa tersebut sebagai akibat belum maksimalnya pengelolaan sumberdaya alam yang ada dan sebagai akibat belum maksimalnya penggerakan tenaga kerja yang ada, maka munculah suatu gagasan untuk memberdayakan masyarakat melalui maksimalisasi pemanfaatan sumberdaya alam dan potensi sumberdaya manusia yang ada di dua desa tersebut. Pemberdayaan masyarakat melalui pemanfaatan sumberdaya alam dan potensi sumberdaya manusia ini diharapkan dapat meningkatkan kesejahteraan masyarakat di dua desa lokasi. Munculnya gagasan ini adalah didasari oleh adanya kesadaran bahwa Perguruan Tinggi (Undiksha dan Unmas) sudah sepantasnya ikut menyumbangkan karya nyata untuk meningkatkan kesejahteraan masyarakat di luar kampus termasuk masyarakat di dua desa lokasi IbW Nusa Penida.

Program Ipteks bagi Wilayah (IbW) di Nusa Penida tahun 2011 diinspirasi dari kondiri dan kebutuhan riil di dua desa, yaitu di Desa Suana dan Desa Batukandik yang menjadi sasaran program. Beberapa kondisi riil yang dimaksud adalah: (1) Bidang Administratif, antara lain: sistem tata layanan masyarakat masih belum optimal, keterampilan staf kecamatan maupun desa dalam pemanfataan komputer dan Internet belum belum optimal; (2) Bidang Pendidikan, antara lain: masih banyak penduduk buta aksara, angka anak-anak putus sekolah di kedua wilayah baik di Desa Suana maupun di Desa Batukandik masih cukup tinggi disebabkan faktor ekonomi dan jarak sekolah; (3) Bidang Peternakan, antara lain: kurangnya pengetahuan tentang pengolahan pakan ternak bagi petani; (4) Bidang Industri, antara lain: pengetahuan tentang pengolahan 
rumput laut, pengolahan pengolahan hasil pertanian, pengolahan hasil perkebunan menjadi produk siap jual di supermakert masih rendah; (5) Bidang prasarana, antar lain: masih ada dusun yang terisolir sehingga roda ekonomi di wilayah tersebut terhambat; (6) Penghijauan, antara lain: lahan tandus di kedua desa masih sangat luas, kurangnya pengaturan tata penghijauan yang sudah ada bagi masyarakat sehingga banyak lahan produktif ditanami pohon jati, kesadaran masyarakat akan pentingnya penghijauan sebagai investasi masa depan masih perlu ditingkatkan.

Terkait dengan beberapa kondisi riil di atas, maka beberapa hal yang dibutuhkan oleh kedua desa sasaran adalah: (1) upaya peningkatan keterampilan staf desa, staf kecamatan dan guru-guru dalam penggunaan komputer dan Internet melalui pelatihan dan pendampingan; (2) upaya pengembangan industri rumahan melalui pemberian pendidikan dan pelatihan di bidang produksi minyak VCO di Desa Ped; (3) pemberdayaan masyarakat petani ternak melalui pembuatan demplot biogas untuk menanfaatkan kotoran ternak sebagai sumber energi; (4) meningkatkan keterampiran proses pembelajaran bagi bagi guru-guru PAUD; (5) meningkatnya keterampilan masyarakat sesuai minatnya sambil mereka belajar membaca dan berhitung melalui program keaksaraan fungsional; (6) meningkatkan keterampilan membuat media pembelajaran berbasis lokal bagi guru-guru IPA; (7) meningkatkan kualitas batako dan dampak lingkungan; (8) meningkatnya pengetahuan masyarakat tentang cara pembibitan dan menanam pohon penghijauan pohon jati dan karet setiap desa; (9) pengembangan budidaya jarak kepyar bekerjasama dengan Kimia Farma.

\section{Metode Pelaksanaan Pengabdian}

Ada beberapa metode/model yang diterapkan dalam pelaksanaan program, yaitu: (1) Model Partisipatory Rural Apprasial (PRA), menekankan keterlibatan masyarakat dalam setiap proses, baik dalam proses melaksanakan identifikasi masalah, perumusan program, maupun pelaksanakan program; (2) Model Enthrepreneurship Capasity Building (ECB), memberikan wawasan, sikap, dan keterampilan usaha, memberikan peluang, memfasilitasi modal pinjamaan, serta mengevaluasi perkembangan usahanya; (3) Model Technology Transfer (TT), menguasai prinsip-prinsip penerapan teknologi terutama yang berkaitan dengan program yang sedang dilaksanakan; (4) Model Information Technology (IT), penyebarluasan informasi dari produk yang telah 
dihasilkan melalui media cetak maupun elektronik. Dalam penerapan metode/model tersebut, masyarakat dilibatkan mulai dari proses perencanaan, proses pelaksanaan hingga proses monitoring dan evaluasi kegiatan. Dalam tahap perencanaan, tim pelaksana mengajak perwakilan masyarakat di duat desa lokasi untuk ikut merencanakan kegiatan yang akan dilaksanakan di masing-masing desa. Pada tahap ini tim pelaksana IbW menggali informasi dari masyarakat tentang hal-hal yang diperlukan dan diinginkan oleh masyarakat dan tentang potensi-potensi yang ada di desa yang dapat dipakai sebagai modal untuk memenuhi keperluan dan keinginan masyarakat. Informasi tentang hal-hal yang diperlukan dan potensi-potensi yang dimiliki oleh masyarakat ini kemudian dipakai dasar oleh tim pelaksana program IbW untuk merencanakan bentuk-bentuk kegiatan. Dalam tahap pelaksanaan, masyarakat di dua desa lokasi secara bersama-sama diajak untuk melaksanakan kegiatan dengan difasilitasi oleh tim pelaksana program IbW. Dalam kegiatan yang berbentuk pendidikan dan pelatihan, masyarakat diposisikan sebagai peserta, sedangkan tutor dan nara sumber diperankan oleh tim pelaksana IbW dan sejumlah nara sumber dari luar tim pelaksana program. Dalam kegiatan yang berbentuk pembinaan dan pendampingan terhadap usaha/industri, masyarakat pemilik dan pengelola usaha/industri diposisikan sebagai pihak yang dibina dan didampingi. Sementara itu pembina atau pendampingnya diperankan oleh tim pelkasana program IbW. Dalam kegiatan pengadaan prasarana fisik, seperti jalan, dan kelestarian lingkungan, seperti penghijauan, masyarakat diposisikan sebagai partisipan kegiatan yang diprakarsai oleh tim pelaksana program $\mathrm{IbW}$.

\section{Hasil dan Pembahasan}

Hasil-hasil yang dicapai dalam kegiatan IbW ini adalah sebagai berikut: (1) Bidang administrasi: dua unit Personal Computer (PC) sudah disumbangkan kepada kedua desa IbW masing-masing 1 unit, serta telah dilatih keterampilan komputer sebanyak 5 orang staf Desa Batukandik, 6 orang staf Desa Suana, 5 orang staf kecamatan Nusa Penida dan 10 guru-guru SD dilatih komputer dan Internet, yang difokuskan pada Ms.Office (Word dan Excel) dan cara akses Internet. (2) Bidang usaha dan industri: telah dilaksanakan pelatihan industri pembuatan VCO Desa Ped sebanyak 26 orang. (3) Bidang peternakan: 4 unit demplot reaktor biogas untuk pemanfaatan kotoran sapi 
sebagai sumber energi yang berlokasi di Desa Batukandik di Desa Ped dan Desa Sakti. Melalui demplot ini, diharapkan biogas sebagai sumber energi rumah tangga dapat disebarluaskan ke masyarakat. (4) Bidang pendidikan: untuk memperkecil angka buta aksara, telah terbentuk kelompok keaksaraan fungsional (KF), seperti: keterampilan membuat jajan, kripik, menjahit bagi peserta perempuan, dan kelompok budidaya jarak kepyar bagi pria di Desa Batukandik. Kegiatan ini dilakukan sambil belajar membaca dan berhitung. Sedangkan di Desa Suana terbentuk kelompok nelayan, dan tani rumput laut dalam meningkatkan kualitas pasca panen. Jumlah peserta peserta yang mengikuti program keaksaraan fungsional (KF), sebanyak 35 orang dari Desa Batukandik, dan 33 orang dari Desa Suana. Di samping itu, juga dilaksanakan program peningkatan keterampilan guru-guru PAUD. (5) Bidang kelestarian lingkungan: telah dilaksanakan pelatihan pembibitan, penyuluhan tentang manfaat pentingnya penghijauan untuk kelestarian lingkungan dan penanaman bibit penghijauan di lahan tandus sebanyak 1.500 pohon jati dan karet untuk setiap desa. (6) Bidang pertanian, mulai tahun 2012 ini di Nusa Penida dikembangkan budidaya jarak kepyar bekerja sama dengan Kimia Farma. Jadi, hasil produksi jarak kepyar akan tampung oleh Kimia Farma dalam memenuhi kebutuhan kekurangan bahan baku.

Berdasarkan keberhasilan program IbW yang telah dicapai dapat dikaji secara lebih mendalam bahwa keterampilan staf desa dan kecamatan masih dipandang perlu ditingkatkan melalui program pendampingan, karena dalam menjalankan tugas pelayanan masyarakat mereka masih sering mengalami kendala, seperti: pembuatan tabel, penataan teks, menyisipkan logo, akses Internet, dll. Produk VCO yang berhasil dibuat, kualitasnya dipandang perlu diuji di laboratorium, dan proses pemasarannya perlu dibantu agar produksi yang dilakukan oleh kelompok pengerajin VCO dapat berkesinambungan. Kemasan produk VCO perlu dibuat unit yang mencirikan kearifan lokal Nusa Penida. Upaya yang dilakukan adalah membentuk kelompok, dan mendirikan koperasi yang akan menampung hasil produksi mereka. Demplot biogas untuk pemanfaatan kotoran ternak sapi telah dibangun di empat lokasi diharapkan dapat berfungsi sebagai media pembelajaran bagi masyarakat, dan dapat mengikis respon negatif yang selama ini berkembang di masyarakat tentang biogas yang dikembangkan oleh lembaga tertentu. Hal ini terus diupayakan agar saatnya nanti, biogas menjadi 
kebutuhan masyarakat sebagai sumber energi rumah tangga. Kelompok-kelompok keaksaraan fungsional (KF) yang terbentuk perlu terus dikembangkan, karena cukup efektif memotivasi masyarakat untuk meningkatkan keterampilannya sambil mereka belajar membaca dan berhitung. Sekolah PAUD yang saat ini mulai berkembang dipandang perlu mendapat pembinaan. Gairah masyarakat dalam hal penghijauan perlu tetap ditumbuhkembangkan, karena dalam jangka panjang sudah banyak yang berhasil meningkatkan perekonomian masyarakat. Jarak kepyar yang dikembangkan bersama Kimia Farma di Nusa Penida diharapkan dapat mendongkrak pendapatan petani, karena dari kekurangan bahan baku sekitar 10.000 ton diharapkan sebagian dapat dipenuhi dari Nusa Penida.

\section{Penutup}

Kesimpulan pelaksanaan program IbW di Nusa Penida pada tahun 2012 telah berhasil dan bermanfaat bagi masyarakat, antara lain: (1) Keterampilan yang dimiliki staf desa, staf kecamatan maupun guru-guru dapat meningkatkan pelayanan masyarakat dalam menjalankan tugasnya; (2) Industri VCO diharapkan menjadi produk unggulan Nusa Penida. (3) Media pembelajaran berbasis lokal dihapakna menjadi media belajar yang efektif bagi siswa. (4) Pembinaan guru-guru PAUD perlu ditingkatkan; (5) Demplot biogas diharapkan menjadi media pembelajaran masyarakat sebagai sumber energi alternatif rumah tangga. (6) Kelompok-kelompok keaksaraan fungsional (KF) secara bertahap dapat memperkecil angka buta aksara, dan meningkatkan keterampilan, serta kesejahteraan masyarakat. (7) Pembinaan terhadap pengerajin batako diharapkan dapat meningkatkan kualitas dan menjaga kerusakan lingkungan. (8) Pentingnya penghijauan lahan tandus dengan tanaman jati dan karet untuk kelestarian lingkungan dan dalam jangka panjang sebagai investasi untuk meningkatkan kesejahteraan masyarakat. (9) Hasil produksi demplot jarak kepyar Nusa Penida menunjukkan hasil yang cukup baik dan diharapkan menjadi komuditi unggulan.

Beberapa dampak dan manfaat dari pelaksanaan program Ipteks bagi Wilayah (IbW) ini adalah: (1) adanya perbaikan tingkat pelayanan masyarakat oleh staf desa, karena adanya penambahan perangkat komputer, serta tingkat keterampilan staf desa; (2) adanya komuditi VCO yang dapat memberi nilai tambah produksi minyak kelapa tradisional; (3) media pembelajaran berbasis lokal diharapkan menjadi media belajar 
yang efektif bagi siswa; (4) pembinaan guru-guru PAUD dapat meningkatkan keterampilannya; (5) adanya demplot biogas dapat dimanfaatkan sebagai media pembelajaran masyarakat tentang sumber energi alternatif rumah tangga; (6) terbentuknya kelompok-kelompok belajar keterampilan sambil belajar membaca dan berhitung, untuk mengurangi angka buta aksara, serta peningkatan kesejahteraan masyarakat; (7) memperkecil dampak lingkungan dalam produksi batako; (8) meningkatnya kualitas lingkungan melalui program penghijauan lahan tandus dan dampak ekonomi jangka panjang; (9) hasil produksi jarak kepyar Nusa Penida diharapkan menjadi komuditi unggulan Nusa Penida.

\section{DAFTAR PUSTAKA}

RPJM Desa Suana.

RPJM Desa Batukandik.

BPS Klungkung. 2008. Nusa Penida dalam Angka, Klungkung: BPS Klungkung.

Ditjen Pengolahan dan Pemasaran Hasil Pertanian, 2006. Program Bio Energi Pedesaan (BEP), Biogas Skala Rumah

Tangga.http://relawandesa.files.wordpress.com/2008/06/biogas-rumah-tangga.pdf Diakses tgl: 02-05-2011.

Pakarmani, 2011. Cara membuat VCO tanpa pemanasan http://pakarmani.blogspot.com/2011/10/membuat-vco-atau-minyak-kelapatanpa.html. Diakses tgl: 05-03-2012. 